Cutcan, Simona. "Text as Palimpsest: Gender in the Work of Agota Kristof." Hungarian Cultural Studies. e-Journal of the American Hungarian Educators Association, Volume 6 (2013): http://ahea.pitt.edu DOI:

\title{
Text as Palimpsest: Gender in the Work of Agota Kristof ${ }^{1}$
}

\section{Simona Cutcan}

\begin{abstract}
This paper investigates the portrayal of gender in the work of Swiss-Hungarian writer Agota Kristof. Texts from her oeuvre that belong to different literary genres and creative periods are analyzed through a framework of materialist feminism, masculinity studies and narratology. Based on an analysis of the incidence of the female voice, two aesthetic strategies can be observed: on the one hand, Kristof's early texts show a certain interest in women's subjectivity, on the other, her later writings foreground male characters and their perspective. Overall, women are portrayed as homebound wives and mothers and men are dominant as narrators, writers and protagonists. While this seems to reflect the patriarchal dichotomy, other elements undermine this reading: male characters are weak and marginal, and in a few significant texts, women's life in the family is represented as a prison from which they wish to escape. In these texts, the female character's voice reveals the internal conflict between her aspirations and the pressures to conform to prescribed roles, which, in some instances, leads to subversion in the form of violence against her husband. Thus, though on the surface Kristof's work seems to reinforce or merely reflect patriarchy, the deeper layers of meaning bring into succeeding focus a fundamental interrogation of gender roles.
\end{abstract}

Keywords: questioning of gender roles, women's objectification, wounded male, exile

Biography: Simona Cutcan studied French and Francophone Languages and Literatures at the University of Pécs in Hungary and French and Spanish Languages and Literatures at the National University of Ireland, Maynooth. Cutcan wrote her doctoral thesis on gender in the work of Swiss Francophone writer Agota Kristof (forthcoming with Peter Lang A.G.), and several articles and conference presentations on the work of the same author. She has also lectured on French women writers Marguerite Duras, Simone de Beauvoir and Marie Darrieussecq. Her research interests include contemporary Francophone women writers, theories of masculinity, feminist literary criticism, and exile, history and trauma in European Francophone literatures.

This paper will explore the relationships between the characters in Agota Kristof's works from a gender perspective and will argue that, when taken together, the texts reflect an ambivalence towards patriarchy and a succession of overwritings of the expected gender hierarchy, a somewhat unconscious palimpsest of deconstruction over conformity to gender roles.

${ }^{1}$ This essay is based on aspects of my doctoral thesis, written in French, which will be published by Peter Lang A.G., Oxford, UK with the title Subversion ou conformisme? La différence des sexes dans l'œuvre d'Agota Kristof. 
Cutcan, Simona. "Text as Palimpsest: Gender in the Work of Agota Kristof." Hungarian Cultural Studies. e-Journal of the American Hungarian Educators Association, Volume 6 (2013): http://ahea.pitt.edu DOI:

Born in Hungary in 1935, Kristof had to leave her country in 1956 after the reprisals against those engaged in the failed revolution endangered the life of her husband. Late in her life she became a well-respected writer in Switzerland and her novels have been translated widely around the world. Her austere and minimalist style and the poignant first-person descriptions of the suffering caused by war and exile struck a chord with a great number of readers. She was awarded many prestigious European literary prizes ${ }^{2}$ but she was probably the most proud of the Kossuth Hungarian National Prize that she received in 2011, the year she died. In an illuminating essay, András Petőcz (2007) argues passionately for Kristof's inclusion in the Hungarian literary patrimony, suggesting that her French sentences have Hungarian inflections and that her trilogy is deeply anchored in her native country. Although Kristof started writing poetry in Hungarian, some of which appeared in the French Irodalmi Újság [Literary Journal] and in the Magyar Mühely [Hungarian Workshop] (Petöcz 2007), once in a francophone environment she wrote only in French and was published mainly by the Editions du Seuil in Paris. During the course of her writing career, Kristof's style changed considerably in response to the adoption of French and to her experimenting with different genres. This shift is illustrated by the fact that, in a recent interview, she expressed the conviction that her early poems written in Hungarian were too lyrical and too romantic and she did not desire to publish them in French (Lathion 2007). Kristof is most famous for her trilogy, composed of Le Grand Cahier [The Notebook] (1986), ${ }^{3}$ La Preuve [The Proof] (1988), and Le Troisième Mensonge [The Third Lie] (1991), which centers on the terrible life of twin brothers Lucas and Klaus T. who are separated because of an unnamed war in an unnamed country at an indeterminate time, in a town given only the initial K. At the end of the first volume of the trilogy that depicts the twins' childhood in their grandmother's house, one of the brothers crosses the border into another country. (The Notebook has been recently adapted for the big screen, and the film, directed by János Szász, has received the prize of the jury at the Karlovy Vary Film Festival.) The second volume of the trilogy deals with Lucas, the brother who stayed at home, and his inability to find happiness without his twin, the truth of which story is questioned at the end of The Proof when his brother returns from abroad. The third novel erases the plot of the previous two volumes and presents the past differently, offering another truth about the cause of the twins' separation and about their lives. Kristof's fourth novel, Hier [Yesterday] (1995), is concerned with main character, Sandor Lester's, difficulties of integration in his unnamed country of adoption, thus continuing the exploration of the theme of exile from the perspective of the life on the other side of the border. The text is composed of short chapters, some of them belonging to the main narrative, others offering a dreamlike prose presented as the writings of the protagonist, but which are in fact the author's adaptations of some of the early unpublished poems. In addition to these novels, eight of Kristof's plays, begun in the 1970s, were published in two volumes, L'Heure grise et autres pièces [The Grey Hour and Other Plays] in 1998 and Le Monstre et autres pièces [The Monster and Other Plays] in 2007. She wrote short texts that were later assembled into a collection of

\footnotetext{
${ }^{2}$ For her oeuvre as a whole, Kristof was given the Prize Gottfried Keller in 2001, the Schiller Prize in 2005, The Austrian Prize for European Literature in 2008 and the Prize of the Neuchâtel Institute in 2009.

${ }^{3}$ The translations of titles and of quotes from works that have not been translated into English are all mine.
} 
Cutcan, Simona. "Text as Palimpsest: Gender in the Work of Agota Kristof." Hungarian Cultural Studies. e-Journal of the American Hungarian Educators Association, Volume 6 (2013): http://ahea.pitt.edu DOI:

short stories entitled C'est égal [Whatever] in 2005 and an autobiographical text, L'Analphabète [The Illiterate], published in 2004 in Switzerland. Kristof's autobiography charts her journey to becoming a writer and emphasises the identity redefinition caused by her exile, which brought the loss of her family, of her culture and particularly her disconnection from the mother tongue. The striking title refers to the paralysing feeling of being illiterate in the new language in which, for the first few years in Switzerland, she could neither read nor write.

Kristof's novels are different from the majority of the novels of women writers in France in the early 1990s, such as, for example, those of Marie Redonnet or Christiane Baroche, significantly because she does not have a female narrator and she does not concentrate on women's everyday lives or on the discovery of their own bodies (Rye and Norton 2002, Counihan 2004). The novels, inspired by the author's own haunting past and many other plays and short stories deal with social and political issues, with a commentary on history and the human condition. Yet, despite this apparent gender neutrality in Kristof's works, the representation of the female characters, who are objects of representation and have minor roles, mainly in the domestic sphere, is ambiguous. Very rarely, women's voices do become central and reveal their unhappiness with their position of powerlessness and dependency in the family. Kristof also dares to explore certain controversial topics like incest and prostitution, doing so without apportioning blame or being judgemental. The reader is asked to identify with the victim and from that position to ponder on the signification of the story, to question the impact of the invisibility of the gender hierarchy and yet of the pervasiveness of its discourses. On the whole, the depiction of female subordination in Kristof's works seems conflicted, and it is as if, between the lines, her work is communicating a message that she was reluctant or unable to articulate explicitly. Is her work a simple representation of a patriarchal society, a subtle interrogation of or even an indictment of women's condition, which is characterised by weakness, selflessness and submissiveness?

Most critics of Kristof have focused on her trilogy, which was analysed with reference to the troubled European past of the second half of the twentieth century and implicitly to her own exile to the western side of Europe, then divided by the Cold War. The absence of explicit female themes has meant that there has been only slight interest in Kristof's female characters, and these have been dealt with in a few critical works in what could be considered only a superficial or summary way (Riboni-Edme 2007, Miletic 2008, Yotova 2011). Although Kristof thematises male loss and alienation, her female characters seem at the mercy of forces out of their control in an even more pronounced way, as women are victims in their family and of social and historical upheavals. Some critics have addressed the narrative style of the trilogy (Petitpierre 2000, Riboni-Edme 2007), but the issues of subjectivity and identity in Kristof's texts have been examined only in connection to the male narrators. However, the reader cannot fail to note that the female voice is marginalised, as narrator, protagonist and character, and this deserves to be investigated. The issue of voice and its authority has been the subject of many feminist literary studies. In this context, a focus on voice represents an attempt to bring the female voice to the fore after its long historical silence and especially its dismissal in canonical literature (Lanser 1992). In line with these concerns - a need to highlight female characters on the level of content and form - we will examine the ways in which Kristof's texts depict the reinforcement or undermining of the subordination of women in society.

Reading a literary text from a gender perspective implies that we analyse the fictional world by taking into account the variable social and cultural meanings given to the biological sexes and to the relations between men and women (Bradley 2013). A gender lens can be applied 
Cutcan, Simona. "Text as Palimpsest: Gender in the Work of Agota Kristof." Hungarian Cultural Studies. e-Journal of the American Hungarian Educators Association, Volume 6 (2013): http://ahea.pitt.edu DOI:

on both the social and individual level, as the social and cultural discourses influence the way a person defines their own identity and their perception of others. The philosopher Nancy Fraser (2003: 22) proposes a bidimensional understanding of gender hierarchy in society: she includes both economic injustice, seen in the unequal social freedoms based on divisions of labour, and cultural androcentrism or the higher prestige and privilege enjoyed by men in society. Both dimensions are relevant for this analysis, as Kristof's female characters are subordinate in their family and undervalued overall. These aspects of gender hierarchy were also discussed by French feminist sociologists Christine Delphy (1992) and Collette Guillaumin (1992) whose reflections I will refer to below. In the following, I shall look at Kristof's works in chronological order, to compare the ways characters are represented in different periods in her work, and to highlight a particular shift in her emphasis regarding the narrative voice. First, I shall briefly evaluate the female voice in the early work, then secondly the male protagonist's voice and characterisation in the trilogy.

Kristof's short stories, written in French as sketches or drafts and initially not intended for publication, convey a general message of nihilism and hopelessness. It is true that in these stories the emphasis is on the experience of male characters, on their loneliness, their lack of relationships, their nostalgia for the past, for the house or the streets of their childhood. There are, however, some significant stories that have in common an interest in women's lives and subjectivities and show the character's psychological struggle in the confines of the family. Seven out of twenty-five short stories have female characters, in six of which women find themselves in a problematic subordinate situation in the family, which I will examine in the following section.

According to the political philosopher Iris Marion Young (2009:110), woman's subordination is possible because her labor of care is unpaid and not valued in society and her isolation in the home makes her a possible victim of abuse: "the gendered structure constrains the opportunities of those persons doing unpaid care work, mostly women. [They]...are rendered dependent on other people for provision of their needs, which makes them vulnerable to poverty or abuse." Young's position is similar to earlier theories of French materialist feminism that find that the roots of familial exploitation lie in the sexual division of labour that makes women dependant. Christine Delphy and Diana Leonard argue that "family oppression is about family subordinates being personal dependants, about women not being able to change to another husband/father easily (or their not being able to change at all), and their having to do whatever their husband/father requires... and his being able to be violent or sexually abusive towards them with relative impunity" (1992:2). Delphy underlined the fact that, in the end, the lack of violence or abuse depends on the good will of the man or, as Anthony McMahon puts it in an analysis of Delphy's work, that "benevolence is the privilege of one who is dominant and is always subject to withdrawal" (McMahon 1999:53). As in Delphy's critique of the male- headed nuclear family, in Kristof's earlier texts, we see that the subordination of the female protagonists in the family is rather the norm.

In Kristof's volume of short stories entitled C'est égal [Whatever], some protagonists talk in their monologues about their desire to change their lives or to find a new home and thus to sever the ties that hold them in an unhappy restrictive relationship. In "La hache" [The Axe], for example, the female protagonist tries to explain to the doctor she summoned that her husband fell from his bed onto an axe while he was asleep, but her recounting of the events does not make much sense and points rather to her being responsible for his death as she cannot hide her relief that he is dead and that she can sleep at last unencumbered. "Chez moi" [At home] gives us the 
Cutcan, Simona. “Text as Palimpsest: Gender in the Work of Agota Kristof." Hungarian Cultural Studies. e-Journal of the American Hungarian Educators Association, Volume 6 (2013): http://ahea.pitt.edu DOI:

monologue of a woman who is dreaming about going away, about finding a home for herself, far from the demands of the others for whom she had to sacrifice the totality of her time: "I will go home, a home I have never had, or that is too far in the past to remember, because it was never, really, a home, ever" [Je rentrerai chez moi, un chez-moi que je n'ai jamais eu, ou trop loin pour que je m'en souvienne, parce qu'il n'était pas, pas vraiment chez moi, jamais] (15). While for this woman fulfilment lies outside her present relationship, which is still an obstacle impossible to overcome, the female character from "Le Produit" [The Product] takes her children with her and leaves her husband, the only one in the volume that managed to escape an abusive relationship.

In addition to the female character's feeling that, as a wife, she has to sacrifice too much of herself because of her duties towards her husband, some of Kristof's short stories also present the issue of prostitution as another psychological bind leading to female subordination. Collette Guillaumin $(1992,1996: 75)$ enriches materialist feminism theory by focusing on what she calls sexage (similar to esclavage, in English, slavery). In its collective and private form, the term applies to the concrete material appropriation of women, of their bodily individuality. Guillaumin indicates that it can take four forms, the appropriation of women's time, of their sexual services, of the obligation to care for the members of the family and of the products of their body, out of which the first three are evident in Kristof's texts. In the short stories I mentioned above it was the appropriation of her time and of the obligation to care for the members of the family that caused the wife's unhappiness, with prostitution in the family being. In the following two examples, prostitution is the appropriation of the body, of the woman's sexual services. "Ma soeur Line, mon frère Lanoé" [My sister Line, my brother Lanoé] and "La mère" [The Mother] tell stories of women who feel that they have to let men use their bodies. The short narratives contain neither the reasons for these women's actions nor any kind of judgement, but force the reader to try to understand them and to question their own assumptions or views on the inequality of the patriarchal world. In "My Sister Line, My Brother Lanoé", Line talks to her brother, whom she loves, about the difficulty of fulfilling what she feels are her duties: "I am a woman, brother Lanoé, I know what I owe to the old man and to you, I am doing it willingly, brother Lanoé, I really want to give my body to anybody. But hold my hand..., while the other is taking me. Love me,... or tie a rope around my neck" [Je suis une femme, frère Lanoé, je sais ce que je dois au vieux et à toi, je le fais de bon cour, frère Lanoé, je veux bien livrer mon corps à n'importe qui. Mais tiens-moi la main..., pendant que l'autre me prend. Aime-moi,... ou noue-moi une corde autour du cou] (45). The girl is a victim, dependent on her brother and her father, and her body does not belong to her. In "La mère" [The Mother], the third person narration presents the return home of the beloved son. The mother is so happy to have her son back that she is willing to overlook everything, even the fact that the young woman that he brought home might be prostituting herself for him. These women are not free, they are slaves to the males in their family.

Kristof's published plays are similar to the short stories in that they allow the voice of some women to be heard. In contrast with the male characters, more preoccupied with money, material existence, with politics, justice and grand ideas, the protection of their community or heroic gestures, the women in the plays, just as in the short stories, are confined to the domestic, to the emotional, they are either dependant on the love of the other or are victims of sexual objectification. The women in their monologues in the plays offer their own interpretation of existence, of changing identity, a certain late awareness of female discontent. The female characters in the plays, especially in the two that I will highlight, are characterised by inertia, 
Cutcan, Simona. "Text as Palimpsest: Gender in the Work of Agota Kristof." Hungarian Cultural Studies. e-Journal of the American Hungarian Educators Association, Volume 6 (2013): http://ahea.pitt.edu DOI:

lifelong passivity and conformity to the opressive gender expectations, resignation, and dependency, taken sometimes to the extreme. They provide a negative and sad portrait of lonely women of a certain age, who are victims of their own illusions and at the same time complicit in their own oppression.

The play La Clé de l'ascenseur [The Key to the Lift] cries to be read from a feminist perspective. Thematically, it ties in with the idea of appropriation of the female body mentioned above. An unnamed old woman tells the story of her secluded life with a husband who out of jealousy keeps her locked in a tower. To keep her away from other men, but telling her it is for for her own good and for the sake of their love, he takes away the key to the lift. Later, to deal with her constant complaints, with the help of a complicit doctor, the husband deprives her one by one of the use of her legs, her ears and eyes. Symbolically, the mutilation of the woman's body reinforces the main idea of the woman as object possessed by the husband. As the story unfolds, the unjust oppression becomes apparent for the protagonist as well as for the public, who witnesses thus the awakening of her awareness of victimhood. First, we can note the way she internalises the patriarchal discourse and she feels guilty. "I have a bad nature. I'm never content... My poor husband! When he would come home in the evening after an exhausting day at work, instead of finding a consoling and good humoured wife, he would only hear moaning" [J'ai une nature mauvaise. Je ne suis jamais contente... Mon pauvre mari! Le soir quand il rentrait d'une journée de travail harassante, au lieu de trouver une femme consolante et gaie, ne trouvait que des gémissements] (73). Later, guilt changes into self-hatred because of her passivity. Only when it becomes clear to her that she is going to lose her voice too, does she rebel. "No! Not my voice! Not my voice, you hear me? My life if you want, but not my voice! No!" [Non! Pas ma voix! Pas ma voix, vous entendez! Ma vie si vous voulez, mais pas ma voix! Non! ](80). The blind, deaf old woman in a wheelchair finds a knife in the doctor's bag and manages to injure her husband. Rennie Yotova (2011:101) is convincing in arguing that the old woman's attack on her husband is a subversive act where she defies his repressive authority. The last words the woman utters about not giving up her voice are a claim for recognition and respect and a desire to tell others about her predicament. Her "poor" husband exemplifies extreme domestic abuse hidden under the mask of respectability and concern for her.

L'Heure grise ou le dernier client [The Grey Hour or the Last Client], which gives the first volume of plays its title, has as a main character an older woman who works as a prostitute. The public sees the last hours of her life, hours that she spends with her old client, a thief who did not like sharing her body with others. He is threatening her with a knife so she has to comply and invent little stories for him, a bit like Sheherazade. Absurdly and unexpectedly, at the end of the play, she is shot by her next-door neighbour. The play continues the theme of the woman's body treated as an object possessed by men, or using Guillaumin's terms (Guillaumin 1995), in this case, collectively appropriated by men. In her youth, the woman decided to sell her body and later, when she was not attractive anymore, to invent dreams and stories in order to get paid. Feeling dehumanised after a life in which her body was used by men and did not belong to herself, realising that she sold herself for the physical and later the emotional maintenance of men, she awaits, unconcerned, for death and even longs for it, viewing it as a deliverance.

The women in these two plays, then, are condemned to solitude; they are tired of their lives, and wish to just stop existing. They share an ambivalent feeling that moves between resignation, regret and desire to change, but yet they are still imprisoned in a role from which they wish they could have escaped earlier. The appropriation of their body and their desire to break free reflects thematically the almost impossible realisation of their freedom as subjects. 
Cutcan, Simona. "Text as Palimpsest: Gender in the Work of Agota Kristof." Hungarian Cultural Studies. e-Journal of the American Hungarian Educators Association, Volume 6 (2013): http://ahea.pitt.edu DOI:

The various female characters in Kristof's short stories and plays have to pay a high psychological price for conforming to what is expected of them, for staying in a dependent relationship where they are not listened to and are not happy and for sacrificing themselves for the love of the other. Romantic love and an internalised sense of duty, discernible in some of the texts, constitute the obstacle to an awareness of inequality and to a desire to change. When they are allowed to speak, the female characters focus on the conflict between their desire for a fulfilling life for themselves and their duties. Kristof thus shows their growing dissatisfaction with the dominant gender discourses and their effort to find their own voice.

Just like Kristof's stories and the plays, thematically the novels also deal with male loss, isolation and nostalgia for an idealised past. Kristof considered her trilogy her magnum opus and wrote it from a deep desire to write about her own past. However, rather than writing directly about her own childhood and her relationship with her brother, she narrates the story of separated twin boys and then, as she described it, her fictional characters started to have a life of their own (Savary 1996).

The Notebook, the first novel, is the first person narrative of nine-year old twin brothers who have to stay during the war with their cruel and distant grandmother in a small provincial border town because the mother could not take care of them anymore in the capital. After a few months, the mother tries to take them back but the twins refuse to leave the grandmother's house to go with her. At that moment, a shell kills both their mother and the baby she was carrying in her arms. Later the children bury the bodies in the garden. After the grandmother's death, the twins continue to live in the house until the arrival of their almost forgotten father who wants to cross the border. The twins decide that one of them should use this opportunity and leave the country. During the crossing, the father is blown up by the mines, and it is his death that allows one of the twins to escape by stepping over his body and thus avoiding the mines.

The Proof is narrated in the third person and for the first seven chapters it tells the story of Lucas, the brother who was left on his own in his grandmother's house. He continues to write in his notebooks, just as the twins had. One night, he comes across a young woman called Yasmine, who was about to drown her newborn baby. Yasmine and her child, Mathias, move in with Lucas. A few years later, Lucas meets Clara, a thirty-five year old librarian. Fascinated by her resemblance to his own mother, he divides his life for a while between his own home and Clara's. After Yasmine's disappearance, Lucas continues to take care of Mathias, who is abused by other children because of his physical deformity. The child feels so unhappy and unloved that he commits suicide at the age of seven. Not long after that, Lucas disappears from the narrative, only to let Claus, the twin brother, appear in the last, eighth chapter. Back in the town of his childhood after forty years, he is trying to find his long lost brother. In the library, he encounters Peter, who at first thinks he sees Lucas. Peter was Lucas's friend and, keeping the promise he had made, he gives Lucas's notebooks to Claus. The epilogue of the novel contains a letter from the police that states surprisingly that, in that town the people mentioned by Claus never existed, with the exception of the grandmother, and that the manuscript intended to be a proof of Lucas' existence was written by Claus, not by somebody else.

The third novel, entitled playfully The Third Lie, starts in the same unnamed town, around the time of the police report, with Claus writing about his own childhood. The reader finds out that his brother did not live with him in the house of the old peasant woman whom he called "grandmother," but that he was on his own after having spent time in a hospital that was bombed during the war. He did cross the border after the old woman's death, but the man whose death allowed him to escape was not his own father. On the other side of the border, he lied to 
Cutcan, Simona. "Text as Palimpsest: Gender in the Work of Agota Kristof." Hungarian Cultural Studies. e-Journal of the American Hungarian Educators Association, Volume 6 (2013): http://ahea.pitt.edu DOI:

the police saying that his name was Claus and that he was eighteen. In fact his name was Lucas and he was only fifteen. The text then moves to the present, to the search for the brother, but this time with the help of the authorities. Lucas goes to the capital, where Klaus lives in the old parental home. Lucas's own narrative ends when he dials his brother's phone number. In the second part of the book, the narrator is Klaus, a poet. Even though during their meeting Klaus realises who the other man is, he pretends he does not. Because he lives with his old mother who can only think about her lost child and because he does not want to disturb their own existence, when questioned, he lies about his own past, erasing any possible links between them. However, Lucas gives his own manuscript to Klaus and Klaus will continue it with his own story. He will write about the incident that caused the destruction of the family: The mother shot the father when she heard that he wanted to leave the family home for another woman and a bullet hit the four year old Lucas by mistake. The mother then had a nervous breakdown and was hospitalised for years. Lucas was taken to a special hospital and Antonia, the father's lover, took care of Klaus until he decided to go back and live with his mother. A few days after meeting Lucas, Klaus is told that his twin brother has taken his own life and the novel ends with the narrator's thoughts about joining his brother as soon as the mother dies.

As we have seen, having men as main characters and narrators in the trilogy means that female characters and their concerns become secondary in these three books, and this subordination is shown on two levels, in content and in form. Women are relegated mainly to the role of occasional objects of desire or unknowable beings, and many are sketchily portrayed as poor and uneducated. The female characters also display a shift from the way some women were depicted in Kristof's earlier work, as they rarely have access to voice. Seemingly, the texts reflect the traditional patriarchal order and do not question the social role that women were made to assume, that of totally dependent and undervalued individuals. However, the texts could as well be read as a negative evaluation of this vision, which is expressed through the male narrator and based on his needs. This interpretation finds support in the negative way male characters are represented. Their roles in the narrative and in the fictional society are deconstructed, questioned, and under appearances of power we uncover weakness, loss of authority, and perception of failure on the personal and social level.

In the trilogy, the preponderance of male narrators is a strategy that allows us to get only their version of events, their choice of episodes and their description of the other characters. Their narrative power is, however, simultaneously undermined as lies upon lies told by the protagonists lead to doubts about their reliability and their identity (as shown in detail by Valérie Petitpierre 2000). For instance, Lucas admits in The Third Lie that The Notebook was a fabrication, "my first lies" [mes premiers mensonges] (49), and that he cannot write the truth as it is too painful (14). Similarly, the police report at the end of The Proof mentions the fact that Lucas told the authorities that his brother existed while in reality there was no trace of him and that the alleged proof, supposedly the text we read, was written by Lucas, not by his twin brother. The complex narrative and the contradictory mirroring stories make the reader question everything s/he reads, even the content of the third novel, which seems to speak the truth.

On the thematic level in all three volumes, we likewise see creativity as male, as the majority of the protagonists are depicted as being obsessed with writing, and writing here represents the desire to communicate and express their innermost thoughts, their isolation and their troubled identity which is caused by loss. Ultimately, the project of utilizing writing to connect the brothers does not succeed because writing does not help to bring them together and it does not lead to a happy resolution. In The Proof they do not meet at all, while in The Third Lie 
Cutcan, Simona. "Text as Palimpsest: Gender in the Work of Agota Kristof." Hungarian Cultural Studies. e-Journal of the American Hungarian Educators Association, Volume 6 (2013): http://ahea.pitt.edu DOI:

they do, but they are not reunited, ultimately only death is able to undo the irreversible fracture. Lastly, the trilogy depicts a patriarchal world, represented by the pillars of the traditional society, the unnamed priest and foreign army officer and the local party chief, Peter, all of whom are father figures for the children who lost their father. Nevertheless, for one after the other, their power in society diminishes, their role is questioned or they doubt their calling. The priest becomes marginalised due to the new atheist regime, and he is tired and old. The foreign officer has to retreat with his army, and the local party chief loses his enthusiasm for the party's cause during the rebellion against the regime that he represents. Moreover, the officer and the party chief are homosexuals, which further endangers their status and undermines a traditional image of masculinity. This blurring of the edges of the rigidly masculine is also visible in the nurturing aspect of the protagonists; for instance, in The Proof, Lucas takes care of Mathias, the handicapped child, because he sees in him his lost brother.

The relations between the sexes as a part of a romantic couple are lacking in all the novels in the trilogy, and it is, rather, the relationship between the twin brothers that determines everything else, with their separation representing the main loss and impacting on other relationships, including those with female sexual partners. The twins' relationship is so strong that nothing else can come between them. When together, they are like one being, when separated they are waiting for each other and no other person can fill the void left by the other brother's disappearance. What is apparent is their unabated feeling of loneliness and their emotional distance from women. Women are either desired, but not attainable, as in the case of Klaus's incestuous love for his half sister in The Third Lie, or are not worth the commitment, and used only for pleasure. When asked what love is, Lucas, in The Proof, says he does not know what the word means, and that the other people do not know either (94).

As the narrative of the trilogy spans across five decades, the narrators' different life stages also influence the way they interact with women and consequently the way these are portrayed. Mainly, women are either sexual objects, as mentioned above, or mother figures. The reiteration of the mother figures in many different guises underlines the problematic aspect of the bond to the parent which they need to reject to become adult men, and in general refers to the idea proposed by sociologist Michael Kimmel that traditional masculinity is a repudiation of the feminine (Kimmel 1994). Supposed to be symbolising unconditional love, the protection of the family, altruism and self-sacrifice, the mother is portrayed in Kristof's trilogy in a ambivalent fashion, as she presents two opposite sides. Sometimes the mother represents rejection for the child, like the mad criminal mother in The Third Lie who does not love the son who nevertheless patiently takes care of her, or affection but also abandonment and powerlessness in The Notebook, where the mother is forced to leave her boys with the estranged grandmother. Antonia, the lover of the twins' father in The Third Lie, can be seen as a warm and caring mother figure, but she reminds the child of the destruction of his own family, for which he considers her, as mistress, responsible. She is a symbol of the adulterous behaviour of his father, who is portrayed as a victim of her power and thus she is condemned by the child. The image of the criminal mother or of the absent, neglectful or mad mother suggests a deep questioning of the ideal mother figure. The mother as leitmotif shows a desire for belonging in the male narrators' lives, a search for origins and implicitly their ambivalent attitudes towards their mother, who, although she is a cause of suffering is still needed.

The plight of the majority of female characters seems overlooked or relegated to the background. The first novel depicts the devastation that the war brings to the whole country. Women watch silently the movement of the troops, they are working the ground on their own or 
Cutcan, Simona. "Text as Palimpsest: Gender in the Work of Agota Kristof." Hungarian Cultural Studies. e-Journal of the American Hungarian Educators Association, Volume 6 (2013): http://ahea.pitt.edu DOI:

doing menial jobs for the survival of the family, left to their own devices after the mobilisation of their husbands. They suffer from poverty, they are raped by the arriving soldiers and some are even killed. In the general chaos, women are the victims and men are the perpetrators of violence. This is sexist violence exacerbated by war, when violence is an everyday occurence. Although their role is secondary, some female characters inspire admiration because they manage to survive and find meaning and purpose in their lives despite all the hardships they have to face. Grandmother from The Notebook, due to her age, avoids the dangers that affect other women in the difficult period of the war. She does not have to conform anymore to gender stereotypes and through determination, hard work and a stubborn effort to be independent, she manages to survive on her own and raises the twins in her way. Marginalized and considered a witch in her community, she is the exception in the trilogy, not being dependent and selfsacrificing. Antonia, in The Third Lie, is constrained by her role in society, she does depend on men, but finds strength in family and children. Women are thus portrayed in their traditional roles of mother, lover and wife and the texts do not challenge overtly these established roles. However, the strength of some female characters together with the undermining of the male protagonists' position on the narrative, personal and social level shake the foundations of the patriarchal hierarchy.

In conclusion, we could say that Kristof's works are not overtly feminist. Her world vision is not strongly marked by her gender, or women's perspectives. Undoubtedly, feminism's concern for social justice can be made visible through raising awareness and gender stereotype deconstruction, through exposing the gender inequalities or the restrictive social norms, and despite her reluctance to continue exploring women's voices, in her later work she continues to expose what it means in her view to be a woman.

On the whole, in Kristof's work we can note different layers and different discourses. The social devalorisation of the feminine is evident, the stereotypes that define the woman by reproduction and sexuality, her objectification and subordination in the family. However, some female characters are inspiring and despite internalising the hegemonic discourses, female identity is seen as a site of struggle between gender role conformism and potential resistance. In one significant text, the woman's survival led to violence against her oppressor. Kristof's most daring play shows the "good wife" as at once unconscious transgressor and unhappy conformist. The woman's awareness of her condition in the couple and implicitly in society is thus problematised. At the same time, although masculinity appears orthodox and traditional the protagonists do the unexpected, they demonstrate a need to nurture and are broken beyond repair because of the loss of important emotional connections, which undermines their superficial independence and strength and on the social level, men are portrayed as marginal and unsuccessful. As a consequence, we can say that, underneath a layer of patriarchal structures that seem to be taken for granted, there is a questioning of traditional gender roles and an effort to show the impact of social norms on individuals. In this way the author succeeds in destabilising the dominant discourses. Hierarchy is still maintained, underlined by the impossibility of harmony or communication between the sexes and seen as an unbridgeable gap, but Kristof points towards the need to reconsider gender relationships, which should be based on equality and mutuality. 
Cutcan, Simona. "Text as Palimpsest: Gender in the Work of Agota Kristof." Hungarian Cultural Studies. e-Journal of the American Hungarian Educators Association, Volume 6 (2013): http://ahea.pitt.edu DOI:

10.5195/ahea.2013.109

\section{Works Cited}

Bradley, Harriet. 2013. Gender, $2^{\text {nd }}$ ed. 'Key Concepts' Series, Cambridge: Polity Press.

Counihan, Francesca. 2004. "Women's Writing in Contemporary France”, Frédéric Royall. ed.

Contemporary French Cultures and Societies. Bern: Peter Lang, 373-394.

Delphy, Christine and Diana Leonard. 1992. Familiar Exploitation, A New Analysis of Marriage in Contemporary Western Societies. Cambridge: Polity Press.

Fraser, Nancy and Axel Honneth. 2003. Redistribution or Recognition? A Political-

Philosophical Exchange. New York:Verso.

Guillaumin, Collette. 1992. Sexe, Race et Pratique du Pouvoir, L'Idée de Nature [Sex, Race and the Practice of Power, The Idea of Nature]. Paris: Côté-Femmes Editions.

- 1995. Racism, Sexism, Power and Ideology, London: Routledge.

- 1996. "The Practice of Power and the Belief in Nature", Diana Leonard and Lisa Adkins eds. Sex in Question: French Materialist Feminism. London:Taylor and Francis, 72-108.

Kimmel, Michael. 1994. "Masculinity as Homophobia", Harry Brod and Michael Kaufman eds. Theorizing Masculinities. Sage Publications, 119-141.

Kristof, Agota. 2004. L'Analphabète. Récit autobiographique [The Illiterate]. Carouge-Genève Zoé.

- 2005. C'est égal [Whatever]. Paris: Seuil.

- 1995. Le Grand Cahier, 1986. Paris: Seuil, coll. Points nº41.

— 1998. L'Heure grise et autres pièces [The Grey Hour and Other Plays]. Paris: Seuil. - 1996. Hier [Yesterday]. 1995. Paris: Seuil, coll. Points n²93.

—. 2007. Le Monstre et autres pièces [The Monster and Other Plays], Paris: Seuil.

—. 1995. La Preuve [The Proof]. 1988. Paris: Seuil, coll. Points n 42.

— 1995. Le Troisième Mensonge [The Third Lie]. 1991. Paris: Seuil, coll. Points n ${ }^{\circ} 126$.

—. 1988. The Notebook, New York: Grove Press.

- 1991. The Proof, New York, Grove Press.

- 1996. The Third Lie. New York: Grove Press. 1997. Yesterday. London: Vintage, Random House.

Lanser, Susan S. 1992. Fictions of Authority, Women Writers and Narrative Voice. Ithaca and London: Cornell University Press.

Lathion, Marie-Thérèse, "Le fonds Agota Kristof aux 'Archives Littéraires de la Bibliothéque nationale suisse" [The Agota Kristof Collection in the Literary Archives of the Swiss National Library]. http://www.revuerectoverso.com/spip.php?article27 accessed on 14 September 2013.

McMahon, Anthony. 1999. Taking care of Men: Sexual Politics in the Public Mind. Cambridge: Cambridge University Press.

Miletic, Tijana. 2008. European Literary Immigration into the French Language, Readings of Gary, Kristof, Kundera and Semprun. Amsterdam: Rodopi.

Petitpierre, Valérie. 2000. D'un exil l'autre, les détours de l'écriture dans la Trilogie romanesque d'Agota Kristof [From Exile to Exile, The Detours of Writing in Agota Kristof's Trilogy]. Carouge Genève: Zoé.

Petőcz András. 2007. "Agota Kristof, a svájci magyar frankofon regényíró" [Agota Kristof, the Swiss-Hungarian Francophone Novelist], foreword to the Hungarian translation of L'Analphabète [The Illiterate]. Budapest: Palatinus Kiadó, http://www.petoczandras.eu/konyvek/analfabeta.html accessed on 14 September 2013. 
Cutcan, Simona. "Text as Palimpsest: Gender in the Work of Agota Kristof." Hungarian Cultural Studies. e-Journal of the American Hungarian Educators Association, Volume 6 (2013): http://ahea.pitt.edu DOI:

Riboni-Edme, Marie-Noëlle. 2007. La Trilogie d'Agota Kristof, Ecrire la division [Agota Kristof's Trilogy, Writing the Division]. Paris: L'Harmattan.

Rye, Gill and Michael Worton. eds. 2002. "Introduction”, Women's Writing in Contemporary France, New Writers, New Literatures in the 1990s. Manchester: Manchester University Press.

Savary, Philippe. 1996. "Agota Kristof: l'implacable mécanique d'une horlogère” [Agota Kristof: The Implacable Mechanism of a Watchmaker]. Matricule des Anges, 14 (Nov/Jan. 1995-6):16-22.

Yotova, Rennie. 2011. La Trilogie des jumeaux d'Agota Kristof [Agota Kristof: The Trilogy of the Twins]. Bienne: Le cippe, Infolio Editions.

Young, Iris Marion. 2009. "Live Body versus Gender", Philomena Essed and Audrey Kobayashi eds. A Companion to Gender Studies. Oxford: Blackwell Publishing, 102-113. 